\title{
PENINGKATAN AKTIVITAS DAN HASIL BELAJAR MATEMATIKA SISWA MELALUI IMPLEMENTASI MODEL KOOPERATIF TIPE THINK PAIR SHARE
}

\author{
${ }^{1}$ Reni Ayuda Petriah, ${ }^{2}$ I Nyoman Gita \\ 1,2Jurusan Pendidikan Matematika \\ Universitas Pendidikan Ganesha \\ Singaraja, Indonesia \\ e-mail: reniap31@gmail.com,nyoman.gita@undiksha.ac.id
}

\begin{abstract}
Abstrak
Penelitian ini bertujuan untuk meningkatkan aktivitas dan hasil belajar matematika siswa kelas XI Jasa Boga 3 SMK Negeri 2 tahun pelajaran 2018/2019 melalui implementasi model pembelajaran kooperatif tipe think pair share. Jenis penelitian ini adalah Penelitian Tindakan Kelas (PTK). Penelitian ini dilaksanakan dalam dua siklus. Setiap siklus terdiri dari 2 pertemuan.Tahapan masing-masing siklus terdiri dari perencanaan, pelaksanaan, observasi, evaluasi, dan refleksi. Data aktivitas belajar siswa diperoleh melalui observasi. Sedangkan, data hasil belajar siswa diperoleh melalui tes evaluasi pada akhir tiap siklus. Hasil penelitian menunjukkan bahwa skor aktivitas belajar siswa pada pertemuan pertama dan kedua siklus I masing-masing adalah 17,67 dan 18,33 dengan kategori tinggi. Pada pertemuan pertama dan kedua siklus II, skor aktivitas belajar siswa masing-masing adalah 20,67 dan 22,33 dengan kategori sangat tinggi. Dari analisis hasil evaluasi belajar siswa, ratarata hasil evaluasi pada siklus I adalah 74,01 dengan ketuntasan klasikal $62,86 \%$. Sedangkan rata-rata hasil evaluasi pada siklus II adalah 82,71 dengan ketuntasan klasikal $85,71 \%$. Hal ini menunjukkan bahwa aktivitas dan hasil belajar siswa dari siklus I ke siklus II mengalami peningkatan. Oleh karena itu, dapat disimpulkan bahwa implementasi model kooperatif tipe think pair share secara optimal dapat meningkatkan aktivitas dan hasil belajar matematika siswa kelas XI Jasa Boga 3 SMK Negeri 2 tahun pelajaran 2018/2019. .
\end{abstract}

Keywords: Penelitian Tindakan Kelas, Think Pair Share.

\begin{abstract}
This research aimed to improve students' activities and learning outcomes at XI Jasa Boga 3 grade SMK Negeri 2 academic year 2018/2019 by implemented cooperative model type think pair share. The type of this research is a classroom action research (CAR). This research was conducted into two cycles. Each cycle consisted of two meetings. Stage of each cycle consisted of planning, acting, observing, evaluating, and reflecting. The data of students' activities was collected through observing. Meanwhile, the data of students' learning outcomes was collected through evaluating test in the end of cycle. The results showed that the score of students' activities learning in the first and the second meeting of cycle I respectively were 17,67 and 18,33 categorized high and very high. In the first and the second meeting of cycle II respectively were 20,67 and 22,33 categorized high and very high. Based on the analisys result from the evaluation of learning outcomes, the average value of the evaluation on cycle I was 74, 01 and and the classical completeness was 62,86\%. Meanwhile, the average value of the evaluation on cycle II was 82,71 and the classical completeness was $85,71 \%$. Those result showed that the students' activities and learning outcomes from cycle I to cycle II increased. Therefore, it can be inferred that the implementation of think pair share cooperative model optimally canimprove students' activities and learning outcomes at XI Jasa Boga 3 grade SMK Negeri 2 academic year 2018/2019.
\end{abstract}

Keywords: Classroom Action Research, Think Pair Share 


\section{Pendahuluan}

Saat ini, perkembangan ilmu pengetahuan semakin pesat yang diiringi dengan pesatnya kemajuan teknologi. Salah satu mata pelajaran yang berperan penting dalam kemajuan teknologi adalah matematika. Akan tetapi, berdasarkan hasil survei Programme for International Student Assessment (PISA) yang dilakukan oleh Organisasi Kerja Sama Ekonomi dan Pembangunan (OECD) pada tahun 2015 pada anak berusia 15 tahun menempatkan bahwa kemampuan matematika siswa Indonesia berada pada peringkat ke-63 dari 72 negara. Di sisi lain, hasil riset Trends in Mathematics and Sciences Study (TIMSS) pada tahun 2015 menunjukkan bahwa Indonesia berada di peringkat 45 dari 50 negara dengan skor 397. Meski demikian, pada acara International Mathematics Contest Singapore IMCS 2017 tim Indonesia mampu meraih 14 emas, 26 perak, dan 50 perunggu. Hal ini membuktikan bahwa sebenarnya Indonesia mampu bersaing dan lebih menggungguli negaranegara lainnya dalam bidang matematika. Oleh karena itu, perlu suatu upaya untuk melakukan perbaikan kualitas pendidikan agar pengetahuan matematika siswa Indonesia meningkat. Peningkatan kualitas pendidikan tidak terlepas dari peran guru dalam proses pembelajaran. Guru memegang peranan penting dalam pembelajaran karena guru yang memiliki andil dalam mendesain perencanaan kegiatan pembelajaran. Kegiatan pembelajaran tidak terlepas dari aktivitas siswa. Aktivitas pembelajaran yang bermakna sangat penting bagi siswa sebagaimana yang dikatakan Supijono bahwa aktivitas bermakna yakni pembebasan untuk mengaktualisasikan seluruh potensi kemanusiaan (Supijono: 2012). Purwanto (2013: 102) mengungkapkan bahwa faktor-faktor yang mempengaruhi berhasil baik atau tidaknya belajar dibedakan menjadi dua golongan, yaitu faktor individual dan faktor sosial. Yang termasuk ke dalam faktor individual antara lain: faktor kematangan/pertumbuhan, kecerdasan, latihan, motivasi, dan faktor pribadi. Sedangkan yang ternasuk faktor sosial antara lain faktor keluarga/keadaan rumah, guru dan cara mengajarnya (model pembelajaran), alat-alat yang dipergunakan dalam belajar mengajar, lingkungan dan kesempatan yang tersedia, dan motivasi sosial. Berdasarkan pendapat tersebut dapat disimpulkan bahwa salah satu faktor yang mempengaruhi hasil belajar adalah model pembelajaran.

Permasalahan pada mata pelajaran matematika juga ditemukan di SMK Negeri 2 Singaraja. Salah satu kelas yang bermasalah dalam pembelajaran matematika adalah kelas $\mathrm{XI}$ Jasa Boga 3. Berdasarkan hasil observasi guru, permasalahan yang terjadi di kelas XI Jasa Boga 3 yaitu kebanyakan siswa tidak bekerja sendiri saat diberikan tugas untuk diselesaikan secara individu. Siswa cenderung menanyakan atau mengutip jawaban temannya. Apabila ada materi yang tidak dipahami, siswa segan bertanya pada guru di kelas dan cenderung bertanya pada teman sebangkunya atau pada teman lainnya yang dianggap lebih bisa. Selain itu, siswa jarang mengajukan pendapat jika diminta untuk mengajukan pendapat. Permasalahan-permasalahan tersebut berdampak pada hasil belajar siswa yang rendah. Rendahnya hasil belajar siswa kelas XI Jasa Boga 3pada mata pelajaran matematika terlihat dari nilai ulangan harian I semester ganjil tahun pelajaran 2018/2019 dengan rata-rata nilai 58,6 dengan ketuntasan klasikal 28\%. Hal ini menunjukkan ketuntasan belajar siswa pada mata pelajaran matematika masih jauh dari yang diharapkan, yaitu minimal $85 \%$ siswa mendapat nilai $\geq 70$.

Sementara itu, berdasarkan hasil observasi peneliti permasalahan yang terdapat pada siswa di dalam kelas saat pembelajaran matematika adalah masih banyak siswa yang kesulitan menyelesaikan soal yang diberikan. Hal ini dikarenakan sebagian besar siswa merasa banyak simbol-simbol dalam matematika seperti pada materi aljabar. Sehingga menyebabkan sebagian besar siswa merasa tidak percaya diri untuk mengerjakan tugas individu saat pembelajaran berlangsung. Ha I iniditunjukkan oleh adanya siswa-siswa yang mengutip/mencontek hasil pekerjaan temannya.Akan tetapi, siswa sangat antusias dalam mengikuti pembelajaran. Hal ini terlihat saat guru sedang menerangkan, siswa dengan serius memperhatikan penjelasan guru. Selain itu, saat guru memberikan tugas siswa selalu berusaha untuk menyelesaikannya.

Berdasarkan permasalahan-permasalahan di atas, perlu dilakukan suatu tindakan agar siswa terbiasa untuk berpikir dan bekerja sendiri. Oleh karena itu, peneliti memilih model 
pembelajaran kooperatif tipe think pair share. Pada model ini terdapat tiga tahap, yaitu tahap think, tahap pair, dan tahap share.

Pada tahap think, siswa diberi kesempatan untuk berfikir dan mencari solusi sendiri dalam menyelesaikan suatu permasalahan matematika yang diberikan. Hal ini dapat menjadi solusi agar siswa terlatih untuk berpikir dan bekerja sendiri sehingga siswa bertanggung jawab secara individu atas tugas dan jawabannya.

Tahapan pair disesuaikan dengan karakter siswa. Siswa sering bertanya kepada teman sebayanya dari materi yang kurang dipahami.

Dari kegiatan-kegiatan yang dilakukan oleh siswa tersebut, maka partisipasi siswa dalam pembelajaran dapat dioptimalisasikan. Optimalisasi ini menyebabkan siswa memiliki banyak aktivitas belajar siswa dalam pembelajaran. Banyaknya aktivitas siswa dalam pembelajaran akan menjadikan pembelajaran bermakna bagi siswa sehingga hasil belajar siswa meningkat.

Terdapat beberapa potensi siswa yang mendukung untuk diterapkannya model pembelajaran kooperatif tipe think pair share di kelas XI Jasa Boga 3SMK Negeri 2 Singaraja. Potensi-potensi tersebut adalah sebagai berikut:

1. Siswa mau mendengarkan pendapat temannya sehingga siswa mempunyai potensi untuk berdiskusi.

2. Sebagian besar siswa sering berdiskusi dengan teman sebangkunya sehingga siswa mempunyai potensi untuk berdiskusi berdua pada tahap pair.

3. Terdapat sebagian besar siswa berkemampuan sedang dan tinggi sehingga diharapkan dapat membantu teman-temannya pada tahap pair maupun share.

Berdasarkan pemaparan-pemaparan di atas, maka peneliti memilih model pembelajaran kooperatif tipe think pair share untuk diimplementasikan di kelas XI Jasa Boga 3 SMK Negeri 2 pada pelajaran matematika tahun pelajaran 2018/2019.

Tujuan yang akan dicapai dalam penelitian ini yaitu untuk menerapkan model pembelajaran kooperatif tipe think pair share untuk hasil belajar matematika siswa kelas XI Jasa Boga 3 SMK Negeri 2 Singaraja Tahun Pelajaran 2018/2019.

Berikut adalah uraian langkah-langkah model kooperatif tipe think pair square dalam penelitian ini adalah sebagai berikut:

1) Guru mengkondisikan siswa untuk siap belajar.

2) Guru menginformasikan materi dan tujuan pembelajaran.

3) Guru memberikan apersepsi dan motivasi tentang materi yang akan dipelajari.

4) Guru menginformasikan langkah-langkah model pembelajaran yang akan digunakan

5) Guru menginformasikan anggota-anggota untuk masing-masing kelompok dan mengatur penggunaan waktu diskusi dengan tepat.

6) Guru membagikan LKPD kepada masing-masing siswa.

7) Siswa mengerjakan LKPD yang dibagikan secara mandiri.(Tahap Think)

8) Siswa berpasangan dengan anggota kelompoknya yang lain untuk berbagi hasil pemikirannya atas permasalahan diajukan guru. (Tahap Pair)

9) Siswa dan teman kelompokanya mempresentasekan hasil diskusinya. (Tahap Share)

10) Guru mengamati jalannya diskusi dan membimbing siswa seperlunya

11) Guru memilih secara acak kelompok yang terbentuk untuk mempresentasikan hasil diskusinya

12) Anggota kelompok lain mencermati dan memberikan tanggapan mengenai hasil diskusi LKPD dari perwakilan kelompok yang mempresentasikan hasil diskusi kelompoknya.

13) Guru bersama siswa membahas kembali hasil diskusi kelompok yang presentasi.

14) Guru memberikan beberapa soalkepada masing-masing siswa untuk dikerjakan secara individu dan dikumpulkan.

15) Guru dan siswa memeriksa tugas individu.

16) Guru bersama siswa memberikan apresiasi berupa pujian kepada kelompok yang yang telah presentasi maupun siswa yang mendapat nilai tertinggi untuk hasil tugas individunya.

17) Guru menutup kegiatan pembelajaran. 


\section{Metode}

Rancangan penelitian adalah semua rencana yang akan dilaksanakan oleh seorang peneliti dalam penelitian untuk menyelesaiakan suatu masalah yang sedang diteliti. Rancangan yang digunakan dalam penelitian ini adalah rancangan penelitian tindakan kelas (PTK) atau Classroom Action Research (CAR).

Masalah pada penelitian ini adalah rendahnya aktivitas dan hasil belajar matematika pada siswa kelas XI Jasa Boga 3 SMK Negeri 2 Singaraja tahun pelajaran 2018/2019. Alternatif pemecahan masalah yang digunakan adalah dengan mengimplementasikan model pembelajaran kooperatif tipe Think Pair Share pada materi fungsi komposisi dan fungsi invers. Tahapan dalam penenlitian ini adalah perencanaan, pelaksanaan, obsservasi/pengamatan, refleksi untuk siklus I. dari hasil refleksi pada siklus I, selanjutnya dilakukan perbaikan pada siklus II. Tahapan pada siklus II adalah perencanaan, pelaksanaan, observasi/ pengamatan, refleksi.

Penelitian ini dilaksanakan di SMK Negeri 2 Singaraja. Subjek dalam penelitian ini adalah siswa kelas XI Jasa Boga 3 SMK Negeri 2 Singaraja semester ganjil tahun pelajaran 2018/2019 yang berjumlah 35 orang. Objek dalam penelitian ini yaitu aktivitas dan hasil belajar siswa pada materi fungsi komposisi dan fungsi invers.

Penelitian ini dilaksanakan dalam 2 siklus. Masing-masing siklus terdiri dari 3 pertemuan. Pada pertemuan pertama dan kedua dilaksanakan kegiatan pembelajaran. Sedangkan pada pertemuan ketiga diadakan evaluasi akhir siklus. Tahapan masing-masing siklus dalam penelitian ini ada 5, yaitu perencanaan, pelaksanaan, observasi, evaluasi, dan refleksi.

Teknik pengumpulan data dalam penelitian ini yaitu data hasil belajar siswa diambil dengan cara memberikan tes pada akhir tiap siklus. Sedangkan data aktivitas belajar siswa dan aktivitas guru diambil menggunakan lembar observasi.

Data-data dalam penelitian ini diambil dengan menggunakan dua instrumen penelitian, yaitu tes evaluasi hasil belajar dan lembar observasi aktivitas belajar siswa. Jenis soal tes yang digunakan untuk mengevaluasi hasil belajar siswa dalam penelitian ini adalah tes pengetahuan dalam bentuk uraian. Sedangkan pada lembar observasi aktivitas belajar siswa dan kegiatan guru terdiri dari 6 indikator, setiap indicator memiliki 3 deskriptor.

Analisis data adalah cara mengolah data yang telah diperoleh. Data yang dianalis is adalah data hasil hasil belajar matematika siswa. Hasil ini diinterpretasikan dan disimpulkan untuk digunakan dalam menjawab permasahan yang telah dirumuskan.

Adapun data yang dikumpulkan untuk dianalisis sebagai komponen untuk diteliti adalah data aktivitas belajar siswa, aktivitas guru, dan hasil belajar siswa setelah diterapkannya model kooperatif tipe think pair share.

Teknik analisis data aktivitas belajar siswa ditentukan dengan menghitung skor aktivitas belajar siswa kemudian menentukan kategori aktivitas belajar siswa menggunakan tabel pedoman yang disusun berdasarkan analisis data aktivitas belajar siswa menggunakan mean ideal $(M i)$ dan standar deviasi $(S D i)$.

Skor aktivitas belajar siswa ditentukan sebagai berikut:

1. Skor 4 diberikan jika $A>75 \%$

2. Skor 3 diberikan jika $50 \%<A \leq 75 \%$

3. Skor 2 diberikan jika $25 \%<A \leq 50 \%$

4. Skor 1 diberikan jika $A \leq 25 \%$

Dengan A adalah banyak siswa yang aktif dalam melakukan kegiatan sesuai dengan deskriptor. berikut:

Untuk menentukan skor rata-rata aktivitas belajar siswa digunakan rumus sebagai

$$
A=\sum_{i=1}^{6} \frac{T_{i}}{n_{i}}
$$

Keterangan:

$A=$ mean (skor rata-rata aktivitas

belajar siswa) 
$\mathrm{T}_{\mathrm{i}} \quad=$ total skoraktivitas belajar siswa pada indikator ke-i

$\mathrm{n}_{\mathrm{i}}=$ banyak deskriptor pada indikator

ke-i.

Pedoman analisis Mi dan SDi adalah sebagai berikut.

Banyaknya indikator $=6$

Skor tertinggi setiap indikator $=4$

Skor terendah indikator $=6$

Skor tertinggi indikator $=24$

$$
\begin{aligned}
& M_{i}=\frac{1}{2} \times(\text { skor tertinggi }+ \text { skor terendah }) \\
& S D_{i}=\frac{1}{6} \times(\text { skor maksimal-skor minimal })
\end{aligned}
$$

(Nurkancana, 1983)

Maka, nilai $M$ dan $S D_{i}$ aktivitas belajar siswa adalah sebagai berikut:

$M_{i}=\frac{1}{2} \times($ skor tertinggi + skor terendah $)$

$$
=\frac{1}{2}(24+6)=\frac{1}{2} \times 30=15
$$

$S D_{i}=\frac{1}{6} \times($ skor maksimal-skor minimal $)$

$$
=\frac{1}{6} \times(24-6)=\frac{1}{6} \times 18,0=3,0
$$

Berdasarkan $M_{i}$ dan $S D_{i}$ dapat disusun kategori aktivitas belajar siswa sebagai berikut (Nurkancana, 1990: 103-104):

Tabel 1. Pedoman Kategori Aktivitas Belajar Siswa

\begin{tabular}{lll}
\hline I n t e r v a l & Skor & Kategori \\
\hline $\mathrm{A} \geq \mathrm{Mi}+1,5 \mathrm{SDi}$ & $\mathrm{A} \geq 19,5$ & Sangat Tinggi \\
$\mathrm{Mi}+0,5 \mathrm{SDi} \leq \mathrm{A}<\mathrm{Mi}+1,5 \mathrm{SDi}$ & $16,5 \leq \mathrm{A}<19,5$ & Tinggi \\
$\mathrm{Mi}-0,5 \mathrm{SDi} \leq \mathrm{A}<\mathrm{Mi}+0,5 \mathrm{SDi}$ & $13,5 \leq \mathrm{A}<16,5$ & CukupTinggi \\
$\mathrm{Mi}-1,5 \mathrm{SDi} \leq \mathrm{A}<\mathrm{Mi}-0,5 \mathrm{SDi}$ & $10,5 \leq \mathrm{A}<13,5$ & Rendah \\
$\mathrm{A}<\mathrm{Mi}-1,5 \mathrm{SDi}$ & $\mathrm{A}<10,5$ & Sangat Rendah \\
\hline
\end{tabular}

Penilaian aktivitas guru dilakukan melalui observasi langsung, dimana seorang guru yang mengajar diobservasi langsung oleh observer. Observer berada bersama-sama guru dan siswa di kelas. Sedangkan data mengenai aktivitas guru diambil dengan menggunakan lembar observasi. Setelah diperoleh data aktivitas guru dari lembar observasi, kemudian data tersebut dianalisis dengan cara sebagai berikut:

Untuk menentukan skor yang diperoleh guru dengan ketentuan sebagai berikut:

1. Skor 4 diberikan jika 3 deskriptor yang tampak.

2. Skor 3 diberikan jika 2 deskriptor yang tampak.

3. Skor 2 diberikan jika 1 deskriptor yang tampak.

4. Skor 1 diberikan jika tidak ada deskriptor yang tampak.

Untuk menentukan persentase keberhasilan guru dalam menerapkan model pembelajaran kooperatiftipe think pair share dengan rumus sebagai berikut: 
$\mathrm{G}=\frac{\sum \mathrm{y}_{\mathrm{g}}}{\mathrm{n}} \times 100 \%$

Keterangan:

$\mathrm{G}=$ persentase aktivitas guru

$\sum y_{g}=$ jumlah skor yang diperoleh guru

$n=$ skor maksimal

(Nurkancana, 1990:99)

Berikut adalah tabel kriteria untuk menentukan aktivitas guru:

Tabel 2 Kriteria untuk Menentukan Aktivitas Guru

\begin{tabular}{ll}
\hline Interval & Kategori \\
\hline $75 \%<\mathrm{G} \leq 100 \%$ & Baik Sekali \\
$50 \%<\mathrm{G} \leq 75 \%$ & Baik \\
$25 \%<\mathrm{G} \leq 50 \%$ & Kurang Baik \\
$\mathrm{G} \leq 25 \%$ & Tidak Baik \\
\hline
\end{tabular}

Data hasil belajar siswa akan dianalisis secara deskriptif yaitu dengan menentukan nilai rata-rata hasil tes tiap akhir siklus dengan rumus, yaitu:

$\bar{x}=\frac{\sum_{i=1}^{n} x_{i}}{n}$

Keterangan:

$\bar{x}=$ Nilai rata-rata skor siswa

$x_{i}=$ Nilai skor masing-masing siswa

$\mathrm{n}=$ Jumlah siswa yang mengikuti tes

(Sudjana, 2002: 67)

Penentuan persentase keberhasilan guru dan kriteria aktivitas guru dijadikan sebagai alat ukur sejauh mana guru dapat menerapkan model pembelajaran kooperatif tipe think pair share secara optimal. Selanjutnya akan digunakan sebagai bahan refleksi untuk memperbaiki serta menyempurnakan perencanaan dan pelaksanaan tindakan pada siklus selanjutnya.

Untuk mengetahui ketuntasan belajar secara klasikal dianalisis dengan menggunakan rumus berikut:

$$
\begin{aligned}
& K K=\frac{X}{N} x 100 \% \\
& \text { Keterangan : } \\
& \text { KK } \quad \text { Ketuntasan klasikal } \\
& \mathrm{X} \quad \text { : Banyaknya siswa yang } \\
& \mathrm{N} \quad \text { memperoleh nilai } \geq 70 \\
& \mathrm{~N} \quad \text { Banyaknya siswa. }
\end{aligned}
$$

Ketuntasan belajar dikatakan tercapai jika $\geq 85 \%$ siswa memperoleh nilai $\geq 70$ sesuai dengan KKM kelas XI yang ditetapkan di SMK Negeri 2 Singaraja.

Indikator keberhasilan penelitian ini adalah hasil belajar siswa meningkat apabila terjadi peningkatan ketuntasan klasikal atau pencapaian ketuntasan klasikal minimal $85 \%$ setelah diterapkan model pembelajaran kooperatif tipe think pair share. 


\section{Hasil dan Pembahasan}

Berdasarkan hasil penelitian, terlihat bahwa rata-rata skor aktivitas belajar siswa mengalami peningkatan pada tiap siklus. Pada siklus I skor rata-rata aktivitas belajar siswa adalah 18,00 dengan kategori tinggi. Pada siklus II, skor rata-rata aktivitas belajar siswa mengalami peningkatan siklus I menjadi 21,51 dengan kategori sangat tinggi. Dengan demikian, dapat dikatakan bahwa implementasi model pembelajaran kooperatif tipe think pair share dapat meningkatkan aktivitas belajar siswa. Pada awalnya yaitu pada pertemuan pertama siklus I, skor aktivitas belajar siswa sudah mencapai kategori tinggi dengan jumlah skor seluruh indokator yaitu 17,67. Pada pertemuan kedua siklus juga mengalami peningkatan jumlah skor seluruh indikator yaitu 18,33 dengan kategori tinggi juga. Peningkatan jumlah skor terjadi pada indikator aktivitas siswa dalam penyajian informasi. Pada pertemuan pertama hanya beberapa siswa yang menanggapi pertanyaan guru saat penyampaian apersepsi dan motivasi. Selanjutnya pada pertemuan kedua jumlah siswa yang menanggapi pertanyaan guru saat penyampaian apersepsi dan motivasi meningkat. Hal tersebut dikarenakan materi apersepsi pada pertemuan pertama adalah materi yang pernah dipelajari pada saat sekolah menengah sehingga banyak siswa yang lupa dengan materi tersebut. Sedangkan pada pertemuan kedua, materi apersepsi yang diberikan adalah materi yang sudah dipelajari pada pertemuan sebelumnya. Selain itu, saat dilaksanakan tahap think sebagian siswa terlihat langsung berdiskusi dengan teman kelompoknya. Hal yang sama terjadi pada tahap pair. Siswa berdiskusi dengan teman kelasnya yang dianggap paling bisa. Pada pertemuanpertemuan berikutnya dilakukan perbaikan-perbaikan atas kekurangan lainnya pada sehingga terjadilah peningkatan aktivitas belajar pada pertemuan 2 siklus I dengan skor rata-rata 18,33. Begitu pula dengan siklus berikutnya yaitu siklus II, dengan melakukan perbaikan di setiap kekurangan-kekurangan yang dilakukan pada pertemuan sebelumnya maka skor aktivitas belajar siswa meningkat dari 20,67 ke 22,33.

Dari uraian di atas dapat disimpulkan bahwa pada siklus I indikator kerja dalam penelitian ini sudah tercapai, namun masih ada kekurangan-kekurangan yang harus diperbaiki lagi. Oleh karena itu,penelitian dilanjutkan ke siklus II kemudian pada siklus II hampir semua kekurangan dapat diatasi.

Sebelum diimplementasikan model-model pembelajaran kooperatif tipe think pair share, aktivitas belajar siswa masih dikategorikan rendah. Hal tersebut terlihat dari hasil observasi yang peneliti lakukan yaitu sebagian besar siswa tidak mengerjakan tugas secara mandiri, siswa cenderung mengutip hasil pekerjaan temannya, dan tidak banyak siswa mengetahui hasil kerja kelompoknya sehingga siswa segan maju saat ditunjuk untuk presentase. Di samping itu, siswa jarang mengajukan pendapat jika diminta untuk mengajukan pendapat. Keadaan semacam ini menunjukkan bahwa aktivitas siswa dalam pembelajaran rendah. Padahal aktivitas belajar siswa yang tinggi dalam pembelajaran menunjukkan bahwa sebagian besar siswa aktif. Keaktifan siswa dalam pembelajaran adalah hal yang paling mendasar yang dituntut dalam pembelajaran karena. Oleh karena itu, dengan menerapkan model-model pembelajaran kooperatif tipe think pair share pada pembelajaran materi fungsi komposisi dan fungsi invers memberikan kesempatan yang besar kepada siswa untuk terlibat aktif dalam pembelajaran.

Model ini memberi siswa kesempatan untuk berkerja sendiri. Di samping itu, siswa juga diperbolehkan bekerjasama berpasangan atau bertiga dengan teman kelompoknya melalui kegiatan diskusi pada tahap pair. Keunggulan dari model ini adalah optimalisasi partisipasi siswa. Optimalisasi partisipasi siswa ditandai dengan diberikan kesempatan lebih banyak kepada siswa untuk menunjukkan partisipasi mereka kepada orang lain. Keunggulan lain dari model ini adalah adanya variasi suasana pola diskusi. Diskusi yang dilakukan siswa dalam model ini hanya dilakukan teman kelompoknya yang terdiri dari satu atau dua orang saja. Halhal yang didiskusikan merupakan hasil pemikirannya pada tahap think. Hal tersebut mengharuskan siswa untuk aktif dalam pembelajaran.

Keaktifan siswa saat implementasi model ini dapat dilihat dari aktivitas-aktivitas siswa. Siswa selalu berusaha mengerjakan tes individu secara mandiri. Sebagian besar siswa sudah tidak lagi mengutip hasil pekerjaan temannya. Banyak siswa yang merespon saat guru 
memberikan pertanyaan pada kegiatan apersepsi dan motivasi. Hal tersebut menunjukkan bahwa siswa telah mempunyai pengalaman sendiri dalam pembelajaran yang dilakukan sebelumnya yaitu setelah diterapakan model TPS. Selain itu, hal tersebut menunjukkan bahwa siswa memiliki keterampilan berkomunikasi dan kemampuan dalam mengemukakan pendapat dalam keadaan non kompetisi. Dengan demikian, hal ini menunjukkan bahwa implementasi model pembelajaran kooperatif tipe think pair share mampu meningkatkan aktivitas belajar siswa.

Sejalan dengan meningkatnya aktivitas belajar siswa, hasil belajar siswa juga akan mengalami peningkatan. Berdasarkan tabel 4.6, terlihat bahwa persentase hasil belajar secara klasikal mengalami peningkatan pada tiap siklus. Pada siklus I nilai rata-rata ketuntasan belajar secara klasikal adalah $62,86 \%$. Pada siklus II rata-rata nilai ketuntasan belajar secara klasikal mencapai $85,71 \%$. Data tersebut menunjukkan bahwa hasil belajar matematika siswa mengalami peningkatan dari siklus I ke siklus II. Dengan demikian menunjukkan bahwa implementasi model pembelajaran kooperatif tipe think pair share mampu meningkatkan hasil belajar matematika siswa. Namun demikian, pada siklus I hasil evaluasi pembelajaran yang diperoleh adalah $62,86 \%$. Ini mengindikasikan bahwa ketuntasan belajar siswa secara klasikal berada dibawah indikator keberhasilan yaitu kurang dari $85 \%$. Keadaan ini menunjukkan bahwa dalam implementasi model pembelajaran kooperatif tipe think pair share pada pembelajaran siklus I belum dilakukakan secara optimal. Pada siklus I siswa belum terbiasa dengan pembelajaran yang mengimplementasikan model pembelajaran kooperatif tipe think pair share. Pada siklus II, persentase ketuntasan hasil belajar secara klasikal mengalami peningkatan menjadi $85,71 \%$ yang telah mencapai indikator keberhasilan yaitu ketuntasan klasikal minimal mencapai $85 \%$. Uraian-uraian tersebut menunjukkan bahwa implementasi model pembelajaran kooperatif tipe think pair share secara optimal dapat meningkatkan hasil belajar matematika siswa.

Berdasarkan uraian-uraian di atas dapat disimpulkan bahwa implementasi model pembelajaran kooperatif tipe think pair share pada materi pembelajaran fungsi komposisi dan fungsi invers dapat meningkatkan aktivitas dan hasil belajar matematika siswa kelas XI Jasa Boga 3 SMK Negeri 2 Singaraja tahun pelajaran 2018/2019.

\section{Simpulan dan Saran}

Berdasarkan analisis data dan pembahasan, maka dapat disimpulkan bahwa:

1. Aktivitas belajar matematika siswa kelas XI Jasa Boga 3 SMK Negeri 2 Singaraja tahun pelajaran 2018/2019 meningkat setelah diimplementasikan model pembelajaran kooperatif tipe think pair share pada materi pembelajaran fungsi komposisi dan fungsi invers. Hal ini berdasarkan data hasil analisis aktivitas belajar siswa pada siklus I dan siklus II. Pada siklus I, rata-rata skor aktivitas belajar siswa mencapai 18,00 dengan kategori tinggi. Pada siklus II, rata-rata skor aktivitas belajar siswa meningkat menjadi 21,50 dengan kategori sangat tinggi.

2. Hasil belajar matematika siswa kelas XI Jasa Boga 3 SMK Negeri 2 Singaraja tahun pelajaran 2018/2019 meningkat setelah diimplementasikan model pembelajaran kooperatif tipe think pair share pada materi pembelajaran fungsi komposisi dan fungsi invers. Hal ini berdasarkan analisis hasil evaluasi belajar siswa pada siklus I dan siklus II. Pada siklus I, nilai rata-rata kelas mencapai 74,01 dengan ketuntasan klasikal $62,86 \%$. Sedangkan pada siklus II, nilai rata-rata kelas mencapai 82,71dengan ketuntasan klasikal $85,71 \%$, dengan kriteria ketuntasan minimal 70 . Hal tersebut menunjukkan terjadi peningkatan pada hasil belajar siswa.

2) Langkah-langkah pembelajaran dalam model kooperatif tipe think pair share secara umum adalah sebagai berikut adalah sebagai berikut:

1) Guru mengkondisikan siswa untuk siap belajar.

2) Guru menginformasikan materi dan tujuan pembelajaran.

3) Guru memberikan apersepsi dan motivasi tentang materi yang akan dipelajari.

4) Guru menginformasikan langkah-langkah model pembelajaran yang akan digunakan 
5) Guru menginformasikan anggota-anggota untuk masing-masing kelompok dan mengatur penggunaan waktu diskusi dengan tepat.

6) Guru membagikan LKPD kepada masing-masing siswa.

7) Siswa mengerjakan LKSyang dibagikan secara mandiri.(Tahap Think)

8) Siswa berpasangan dengan anggota kelompoknya yang lain untuk berbagi hasil pemikirannya atas permasalahan diajukan guru. (Tahap Pair)

9) Siswa dan teman kelompokanya mempresentasekan hasil diskusinya.(Tahap Share)

10) Guru mengamati jalannya diskusi dan membimbing siswa seperlunya

11) Guru memilih secara acak kelompok yang terbentuk untuk mempresentasikan hasil diskusinya

12) Anggota kelompok lain mencermati dan memberikan tanggapan mengenai hasil diskusi LKPD dari perwakilan kelompok yang mempresentasikan hasil diskusi kelompoknya.

13) Guru bersama siswa membahas kembali hasil diskusi kelompok yang presentasi.

14) Guru memberikan beberapa soalkepada masing-masing siswa untuk dikerjakan secara individu dan dikumpulkan.

15) Guru dan siswa memeriksa tugas individu.

16) Guru bersama siswa memberikan apresiasi berupa pujian kepada kelompok yang yang telah presentasi maupun siswa yang mendapat nilai tertinggi untuk hasil tugas individunya.

17) Guru menutup kegiatan pembelajaran.

Berdasarkan kegiatan dan hasil penelitian, maka saran-saran yang dapat peneliti kemukakan adalah sebagai berikut:

1. Selalu perhatikan waktu saat pelaksanaan kegiatan pembelajaran agar sesua dengan alokasi waktu perencanaan pembelajaran.

2. Pastikan seluruh siswa melakukan instruksi yang diberikan guru untuk setiap tahapan pembelajaran.

3. Rencanakan seluruh kegiatan pembelajaran secara maksimal dengan baik agar tujuan pembelajaran dapat tercapai dengan baik.

4. Laksanakan seluruh kegiatan pembelajaran sesuai dengan perencanaan.

\section{Daftar Pustaka}

Nurkancana, W. dkk. 1983. EvaluasiPendidikan. Surabaya: Usaha Nasional.

Nurkancana, W., PPN Sunartono. 1990. Evaluasi Hasil Belajar. Surabaya : Usaha Nasional.

Sudjana. 2002. Dasar-Dasar Proses Belajar Mengajar. Bandung: Sinar Baru Algensindo

Suprijono, Agus. 2009. Cooperatif Learning. Yogyakarta: Pustaka Pelajar 